\title{
Analisis Peran Kepala Sekolah dalam Pelaksanaan Total Quality Management di Sekolah Dasar Negeri Bulukantil
}

\author{
Muna Fauziah \\ Institut Agama Islam Nahdlatul Ulama Kebumen \\ fauziah@iainu-kebumen.ac.id
}

\section{Article History}

received 22/10/2021

revised 12/11/2021

accepted 24/12/2021

\begin{abstract}
This study aims to analyze the role of the principal and describe the implementation of total quality management at the Bulukantil State Elementary School. The research uses a qualitative approach. The research subject is the principal of the Bulukantil State Elementary School, Surakarta, and Central Java. Research data obtained through interview techniques, observation, and questionnaires. The data validity technique uses triangulation. Analysis of research data using interactive analysis techniques. The stages of analysis are data reduction, data presentation, and verification/drawing conclusions. There are two research conclusions, namely the principal has played a role in various aspects of the implementation of total quality management, both the role of educators, managers, administrators, leaders, innovators, motivators, and supervisors with a percentage of $81.24 \%$ and the implementation of total quality management in Bulukantil State Elementary Schools. has gone well through the stages of planning, organizing, mobilizing, measuring, and monitoring. So, it can be concluded that the implementation of total quality management at the Bulukantil State Elementary School has been in accordance with the stages and is supported by the various roles of the principal in the school.
\end{abstract}

Keywords: Total quality management, the role of the principal, implementation

\begin{abstract}
Abstrak
Penelitian ini bertujuan untuk menganalisis peran kepala sekolah dan mendeskripsikan pelaksanaan total quality management di Sekolah Dasar Negeri Bulukantil. Penelitian menggunakan pendekatan kualitatif. Subjek penelitiannya yaitu kepala sekolah dasar Negeri Bulukantil, Surakarta, Jawa Tengah. Data penelitian didapat melalui teknik wawancara, observasi, dan angket. Teknik validitas data menggunakan triangulasi. Analisis data penelitian menggunakan teknik analisis interaktif. Tahapan analisisnya yaitu reduksi data, penyajian data, dan verifikasi/penarikan kesimpulan. Ada dua kesimpulan penelitian yaitu kepala sekolah melakukan perannya dalam berbagai aspek pelaksanaan total quality management, baik peran educator, manajer, administrator, leader, innovator, motivator, dan supervisor dengan presentase $81,24 \%$ dan pelaksanaan total quality management di Sekolah Dasar Negeri Bulukantil telah berjalan dengan baik melalui tahap perencanaan, pengorganisasian, penggerakan, pengukuran, dan pengawasan. Maka, dapat disimpulkan bahwa implementasi total quality management di Sekolah Dasar Negeri Bulukantil telah sesuai dengan tahapantahapannya dan didukung dengan berbagai peran kepala sekolah di sekolah.
\end{abstract}

Kata kunci: Total quality management, peran kepala sekolah, pelaksanaan 


\section{PENDAHULUAN}

Pembangunan sebuah Negara tidak hanya berfokus pada aktivitas ekonomi penduduk saja, tetapi juga pembangunan dapat terwujud melalui peningkatan pendidikan, dari jenjang taman kanak-kanak hingga perguruan tinggi. Pembangunan dalam bidang pendidikan diarahkan pada peningkatan kualitas peserta didik, guru, maupun kepala sekolah. Kepala sekolah menjadi pejabat tertinggi di sebuah instansi yang bernama sekolah. Kepala sekolah sangat berperan dalam pengembangan mutu pendidikan di sekolah yang di bawah wewenangnya. Kepala sekolah harus mampu memimpin dengan baik melalui pelaksanaan system manajemen mutu sekolah. Istilah system manajemen mutu dikenal dengan istilah asing Total Quality Management atau disingkat TQM. TQM merupakan system manajemen mutu dengan strategi dan usaha yang diorientasikan kepada kepuasaan pelanggan dengan melibatkan seluruh stakeholders (Zahroh, 2015). Keberadaan TQM juga ditenggarai oleh Peraturan Pendidikan RI Nomor 19 Tahun 2005 yang berisi standar pendidikan nasional yang harus dicapai dalam sebuah lembaga pendidikan, seperti standard isi, proses, kompetensi lulusan, pendidik dan tenaga kependidikan, sarana dan prasarana, pengelolaan, pembiayaan, dan penilaian pendidikan.

TQM merupakan program yang banyak mengalami kendala dalam pelaksanaannya sehingga perlu usaha preventif untuk menghasilkan capaian yang maksimal. Pemerintah telah mengupayakan keunggulan masyarakat bangsa dalam penguasaan ilmu dan teknologi yang berkualitas dan berkelanjutan secara mikro dalam bidang pendidikan untuk meningkatkan efisiensi, mutu, dan pemerataan pendidikan (Mulyasa, 2011). Harapan tersebut dapat terealisasi jika ada pemimpin lembaga yang berkompeten. Hal ini dikarenakan keberhasilan lembaga juga dipengaruhi oleh peran kepala sekolah. Pernyataan ini sejalan dengan pendapat Hidayati (2015) bahwa keberhasilan lembaga terlihat dari kualitas dan mutunya. Untuk melihat dua hal tersebut, perlu peran pendidik dan kepala sekolah untuk mewujudukan standar pendidikan nasional dengan didukung oleh banyak pihak.

Kepala sekolah seharusnya menguasai semua pengetahuan, teknologi, dan perkembangan kesenian sesuai era saat ini. Menurut Marmoah (2016), kepala sekolah juga harus mampu menjawab kebutuhan pengguna jasanya dengan mengembangkan sikap dan keterampilan. Kepala sekolah memerlukan teknik ataupun strategi dalam pencapaian hasil output dan outcome yang bermutu, mampu melihat segala perubahan regulasi pendidikan, serta mampu membawa perubahan yang lebih baik. Sejalan dengan itu, kemampuan professional kepala sekolah sangat perlu dimiliki oleh kepala sekolah (Wahjosumidjo, 2005).

Fenomena yang terjadi saat ini ialah kualitas perekrutan kepala sekolah yang kurang transparan. Temuan lain oleh Prestiadi et al. (2015) bahwa pelaksanaan TQM di sekolah belum maksimal terutama dalam pengembangan diri guru. Oleh karena itu, kepuasan pelanggan pun berkurang karena guru dianggap kurang kompeten. Kurang maksimalnya pengembangan guru juga disebabkan oleh kurangnya motivasi dan wawasan guru maupun kepala sekolah tentang pengembangan keprofesian. Fenomena seperti ini akan mengakibatkan rendahnya produktivitas kerja kepala sekolah yang berimplikasi juga pada mutu (input, proses, dan output). Temuan tersebut sama dengan temuan Lubis (2015) bahwa mutu pendidikan kurang maksimal akibat dari manajemen kepemimpinan kepala sekolah yang rendah. Selain itu, kesiapan daerah dalam pelaksanaan desentraisasi pendidikan juga masih pada tahap kesiapan psikologis. Sementara itu, kesiapan teknis dan profesionalitasnya belum optimal.

Hasil uji kompetensi kepala sekolah (UKKS) dari Kementerian Pendidikan dan Kebudayaan pada tahun 2015 hanya mencapai nilai rerata 56,37 saja (Kementerian Pendidikan dan Kebudayaan, 2015). Sajian data ini menunjukkan bahwa kinerja 
Kepala Sekolah di Indonesia dalam pelaksanaan tugas dan fungsinya sebagai pengelola masih rendah dan diperlukan perhatian yang lebih serius dalam peningkatan kompetensi untuk setiap dimensi kompetensinya.

Keadaan semacam ini jika tidak segera ditindaklanjuti, maka akan menghambat pencapaian tujuan organisasi sekolah. Apabila masalah tersebut dibiarkan, maka akan menimbulkan akibat fatal di berbagai aspek, seperti menurunnya tingkat kredibilitas seorang kepala sekolah dan tidak terkontrolnya pelaksanaan manajemen berbasis sekolah di satuan pendidikan. Hal ini sesuai dengan pendapat Fitrah (2017) yang menyatakan bahwa apabila Kepala Sekolah tidak memiliki kemampuan untuk mentransformasikan ide dan imajinasi atau hanya memiliki visi dan misi mendapatkan jabatan, maka melemahnya kepercayaan masyarakat terhadap sekolah semakin tinggi dan lebih parahnya akan berdampak pada penutupan sekolah yang dipimpin oleh kepala sekolah tersebut.

Fenomena yang terjadi dapat diatasi dengan pengoptimalan peran kepala sekolah dalam pelaksanaan TQM. Sesuai dengan definisinya, TQM merupakan himpunan prinsip, alat, dan prosedur dalam penyelenggaraan organisasi (Anjarwati, 2016). Pengoptimalan TQM dapat diukur dengan melihat aspek perencanaan, pengorganisasian, penggerakkan, pengukuran, dan pengawasan. Dalam perencanaan, kepala sekolah berperan untuk menggagas rencana-rencana program yang akan dilakukan selama periode mendatang. Ini sejalan dengan pendapat (Supriyanto, 2011) bahwa sebuah perencanaan dan pendekatan organisasi merupakan factor dalam kesuksesan organisasi. Kepala sekolah juga berperan untuk menetapkan keputusan dari program yang telah disepakati bersama. Kemudian, aspek pengorganisasian, kepala sekolah berperan untuk mengelola atau membentuk tim pelaksana TQM di lapangan. Sekolah memerlukan tim khusus pelaksanaan TQM beserta struktur dan tugas pokoknya. Tim khusus harus jelas dan detail sehingga kepala sekolah akan mudah memantau kinerja timnya. Selanjutnya, aspek penggerakkan, kepala sekolah berperan untuk menggerakan anggotanya dalam pengimplementasian programprogram yang telah direncanakan. Aspek pengukuran dilakukan oleh kepala sekolah dengan menilai tingkat ketercapaian program. Terakhir, peran kepala sekolah dalam aspek pengawasan dilakukan dengan cara mengawasi setiap pergerakan program. Jika terjadi kendala, kepala sekolah harus segera mengevaluasi pelaksanaan program.

Terkait dengan peran penting kepala sekolah dalam pelaksanaan TQM, maka penulis akan mencoba memotret peran kepala sekolah dalam pelaksanaan TQM secara lebih rinci atau dilakukannya penelitian secara mendalam agar diperoleh data yang akurat yang sesuai dengan teori-teori yang ada maupun teori yang berlainan. Penelitian ini bertujuan untuk menganalisis peran kepala sekolah dalam pelaksanaan TQM di SD Negeri Bulukantil dan mendeskripsikan pelaksanaan pelaksanaan TQM di SD Negeri Bulukantil.

\section{METODE}

Pendekatan penelitian yang digunakan adalah penelitian kualitatif (Creswell, 2014). Penelitian kualitatif digunakan karena tujuan penelitian ini adalah untuk menganalisis peran kepala sekolah dalam pelaksanaan TQM di SD Negeri Bulukantil dan mendeskripsikan pelaksanaan pelaksanaan TQM di SD Negeri Bulukantil. Penelitian dilaksanakan di SD Negeri Bulukantil sebagai sekolah rujukan pelaksana TQM di Kecamatan Jebres, Surakarta. Data penelitian didapat melalui teknik wawancara, observasi, dan angket. Teknik wawancara dikumpulkan melalui lembar pedoman wawancara untuk mendeskripsikan pelaksanaan pelaksanaan TQM di SD Negeri Bulukantil. Sementara itu, teknik penyebaran angket melalui lembar angket (skala likert) yang ditujukan untuk menganalisis peran kepala sekolah dalam pelaksanaan TQM di SD Negeri Bulukantil. Teknik yang digunakan untuk menguji 
keabsahan data dalam penelitian ini yaitu teknik triangulasi sumber dan teknik. Penelitian ini menggunakan teknik analisis flow model. Miles dan Huberman (Sugiyono, 2016) mengungkapkan ada tiga komponen analisis yaitu reduksi data (data reduction), penyajian data (data display), dan verifikasi data.

\section{HASIL DAN PEMBAHASAN}

Penelitian ini dilakukan menggunakan dua teknik yaitu: wawancara dan angket. Wawancara dilakukan kepada kepala SD Negeri Bulukantil, sedangkan angket ditunjukkan kepada guru SD Negeri Bulukantil. Hasil penelitian diuraikan sebagai berikut.

Hasil penelitian yang pertama ialah tentang peran kepala sekolah dalam pelaksanaan TQM, peneliti memperoleh data melalui metode angket. Dalam hal ini, data yang terkumpul diproses dan dituangkan dalam bentuk angka-angka. Selanjutnya, data ditafsirkan secara deskriptif. Berikut ini merupakan hasil data penyebaran angket dari 9 orang guru mengenai peran kepala sekolah dalam pelaksanaan TQM di SD Negeri Bulukantil.

Tabel 4.1. Peran Kepala Sekolah dalam Pelaksanaan TQM

\begin{tabular}{clccc}
\hline No. & Aspek & Skor Perolehan & Presentase (\%) & Kategori \\
\hline 1 & Educator & 92 & 80 & Terbiasa \\
2 & Manajer & 93 & 80,87 & Terbiasa \\
3 & Administrator & 91 & 79,13 & Mulai Terbiasa \\
4 & Leader & 94 & 81,74 & Terbiasa \\
5 & Innovator & 95 & 82,61 & Terbiasa \\
6 & Supervisor & 94 & 81,74 & Terbiasa \\
7 & Motivator & 95 & 82,61 & Terbiasa \\
\hline
\end{tabular}

Data tersebut memberikan makna bahwa kepala sekolah telah terbiasa memerankan perannya dalam pelaksanaan TQM. Presentase yang diperoleh secara keseluruhan $81,24 \%$ atau terbiasa. Hal ini meliputi tujuh aspek yaitu educator, manajer, administrator, leader, innovator, motivator, dan supervisor. Penjelasannya sebagai berikut:

Pertama, kepala sekolah telah melaksanakan peran sebagai educator yang ditandai dengan pemberdayaan system penghargaan sebagai bentuk apresiasi kepala sekolah kepada kinerja karyawannya. Kepala sekolah juga telah menetapkan targettarget perbaikan yang berkelanjutan untuk meningkatkan standar sekolah. Temuan ini sejalan dengan hasil observasi bahwa kepala sekolah terlihat ikut serta dalam rapat internal yang membahas mengenai target capaian standar sekolah. Kepala sekolah sesekali terlihat melempar senyum dan ucapan terima kasih selepas bertemu guru yang baru melakukan pembelajaran. Saat berangkat sekolah, kepala sekolah juga ikut berbaris di dekat pintu gerbang untuk menyapa peserta didik ataupun wali peserta didik yang mengantar ke sekolah. Hal tersebut mencerminkan bahwa kepala sekolah telah terbiasa melaksanakan perannya sebagai educator. Hal yang dapat dilakukan sebagai educator yaitu memberikan dorongan kepada seluruh tenaga kependidikan untuk memperbaiki kualitas pelayanan sekolah (Danim, 2006).

Kedua, kepala sekolah telah terbiasa melakukan perannya sebagai manajer. Senada dengan perolehan angket, temuan observasi juga memperlihatkan bahwa kepala sekolah nampak terlibat langsung untuk mengajar dan ikut serta mengatur konsep perlombaan yang akan dilaksanakan di sekolah. Kepala sekolah membuat aturan-aturan sekolah dan ikut menentukan bahan-bahan yang diperlukan oleh guru selama pembelajaran. Kepala sekolah berusaha untuk memenuhi kebutuhan pelanggannya, baik dari sarana dan prasarananya maupun keperluan proses pembelajaran. Kepala sekolah berusaha melayani pelanggan agar sesuai dengan 
harapan-harapan mereka. Kepala sekolah melibatkan semua karyawan dalam peningkatan mutu sekolah, baik dalam pengambilan keputusan, pelaksanaan program, maupun pengembangan tugas-tugas mereka. Pelayanan tersebut bertujuan untuk mengembangkan kompetensi organisasi dan meningkatkan nilai organisasi bagi pelanggan pendidikan (Jusuf, 2013).

Ketiga, kepala sekolah telah melakukan perannya sebagai leader. Kepala sekolah berusaha memberikan contoh pelayanan yang baik dalam memuaskan pelanggan sehingga guru dan karyawan termotivasi untuk mengikuti jejaknya. Temuan observasi juga memperlihatkan adanya keterlibatan kepala sekolah dalam perencanaan pengembangan keprofesian guru. la nampak ikut menentukan program yang akan dilaksanakan. Contoh sederhana lainnya yaitu kepala sekolah ikut melakukan kerja bakti bersama guru dan peserta didik di sekolah. Kegiatan tersebut menjadi penting karena kepala sekolah sedang memberikan pengarahan pentingnya kontribusi dan peran mereka dalam pengembangan sekolah. Kepala sekolah menggunakan analisis fakta dan informasi yang objektif dalam peningkatan kualitas sekolah.

Keempat, kepala sekolah sebagai administrator. Peran yang dilakukan yaitu kepala sekolah memberikan kewenangan kepada guru memberikan penilaian perkembangan peserta didik yang berbasis IT maupun manual. Hasil observasi serupa juga ditunjukkan oleh kepala sekolah. la ikut terlibat menjadi tim pengelola kurikulum sekolah. la juga ikut menjadi pengajar di beberapa kelas apabila ada guru yang tidak bisa berangkat sekolah. Saat mengajar, kepala sekolah nampak melakukan penilaian sebagaimana mestinya yang dilakukan seorang guru. Kepala sekolah menggunakan informasi yang objektif dalam pengambilan keputusan. Menurut Purwanti (2013), kepala sekolah harus ikut serta mengelola kurikulum, administrasi sarana dan prasarana, administrasi kearsipan, dan administrasi keuangan.

Kelima, kepala sekolah sebagai innovator. Kepala sekolah menyediakan fasilitas lengkap proses pembelajaran dengan pemberdayaan lingkungan maupun media sebagai sumber belajar. Sekolah menyediakan laptop untuk guru dalam mengajar. Kepala sekolah memberdayakan guru untuk mengikuti program pelatihan dan pengembangan kinerja guru secara teratur. Pada beberapa kesempatan, kepala sekolah ikut terlibat dalam kegiatan KKG di sekolah dalam satu gugus. la ikut membuka kegiatan KKG dan mendampingi guru selama kegiatan KKG berlangsung. Hal ini dikarenakan adanya program teratur akan membantu peningkatan kualitas pendidik di sekolah. Temuan ini sejalan dengan studi sebelumnya yang menghasilkan temuan bahwa kegiatan pelatihan bermanfaat bagi pengetahuan guru pribadi sehingga guru semakin termotivasi untuk berkembang dan kualitas pembelajaran semakin baik (Fitrah, 2017; Nurhayati et al., 2018).

Keenam, kepala sekolah telah melaksanakan perannya sebagai supervisor. Kepala sekolah memberikan kewenangan kepada karyawan untuk mengendalikan dan meningkatkan kualitas kerja mereka. Kepala sekolah mengembangkan keterlibatan karyawan pada semua aspek bagian kualitas sekolah. Hasil pengamatan menunjukkan bahwa kepala sekolah telah melakukan supervisi langsung kepada tenaga pendidik atau kependidikan. la tidak segan untuk menegur bawahannya yang tidak melaksanakan aturan sekolah. Sahertian (2000) yang menyatakan bahwa kepala sekolah sebagai supervisor mempunyai peran dan tanggung jawab membina, memantau, dan memperbaiki proses pembelajaran aktif, kreatif dan menyenangkan. Sejalan dengan itu, temuan Esia-donkoh (2018) bahwa peran kepala sekolah sebagai supervisor terbukti mampu memotivasi guru dan mempererat hubungan antara kepala sekolah dengan guru. Selain itu, studi penelitian (Yang et al., 2018) juga menemukan hasil yang serupa dimana kepala sekolah sebagai supervisor untuk pengembangan karis memiliki hubungan positif antara kepuasan guru dan promotabilitas. 
Ketujuh, peran kepala sekolah sebagai motivator. Kepala sekolah memotivasi semua karyawan untuk meningkatkan mutu melalui memberikan saran yang membangun bagi sekolah. Dalam beberapa kesempatan, kepala sekolah terlihat mengajar guru untuk ikut serta dalam kegiatan seminar atau workshop external. la juga memotivasi guru untuk melakukan kenaikan pangkat dengan melakukan penelitian di kelasnya sendiri. Kepala sekolah juga menyediakan informasi mengenai seminar/workshop sehingga semua karyawan dapat ikut kegiatan tersebut. Menurut Haryanto \& Lurah (2014), pemberian motivasi dapat dilakukan dengan cara memberikan penghargaan bagi warga sekolah yang berprestasi. Sama halnya dengan teori lqbal et al. (2017) bahwa motivator disebut sebagai pemuas yang meningkatkan kepuasan kerja sehingga para pekerja/guru lebih antusias untuk melakukan pekerjaan yang ditugaskan oleh atasannya.

Beberapa peran yang telah diuraikan di atas, memberikan arti bahwa kepala sekolah telah memerankan tugasnya sebagai Kepala Sekolah dalam pelaksanaan TQM ditandai beberapa aspek yaitu educator, manajer, administrator, leader, innovator, motivator, dan supervisor. Hasil tersebut sesuai dengan hasil wawancara dan observasi Kepala Sekolah yang masih dalam irisan pelaksanaan TQM. Dengan demikian, perannya dalam pelaksanaan TQM sudah dilakukan dengan maksimal.

Temuan kedua berisi tentang pelaksanaan TQM di SD Negeri Bulukantil Ada beberapa hal yang menjadi sub focus penelitian berkaitan dengan pelaksanaan TQM yaitu perencanaan, pengorganisasian, penggerakkan, pengukuran, dan pengawasan. Penjelasannya sebagai berikut.

Perencanaan berkaitan dengan strategi yang dilakukan sekolah dalam melaksanakan suatu program. Dalam merencanakan, sekolah harus memahami makna penting dari mutu pendidikan. Sekolah mendefinisikan makna mutu pendidikan sebagai kewajiban sekolah dalam rangka mewujudkan tujuan pendidikan nasional. Hal ini disampaikan melalui wawancara dengan kepala sekolah yang menyatakan "mutu pendidikan adalah wajib ditingkatkan bagi setiap sekolah dalam rangka mewujudkan tujuan pendidikan nasional". Sekolah menggambarkan mutu pendidikan menjadi tanggung jawab semua elemen sekolah, baik kepala sekolah, guru, peserta didik, komite, dan orang tua peserta didik. Kepala sekolah menyatakan dalam wawancara, "Mutu pendidikan adalah tanggung jawab kepala sekolah, guru, dan orang tua peserta didik". Jadi, mutu pendidikan tidak bisa dipisahkan dengan semua yang berwenang dalam kemajuan sekolah. Hasil pengamatan juga menghasilkan temuan serupa dimana seluruh pihak sekolah terlibat dalam setiap kegiatan sekolah. Mereka nampak kompak dan bekerja sama dalam peningkatan kualitas pendidikan, seperti saat kegiatan lomba antar sekolah. Guru saling bahu membahu membantu peserta didik untuk pelatihan lomba di sekolah. Setiap guru mendapat tugas untuk melatih peserta didik, baik lomba membaca puisi, cerdas cermat, dan lomba lainnya.

Kepala sekolah mengatur penuh program sekolah, akan tetapi tetap mempertimbangkan pendapat guru dan memberikan peran guru dalam pelaksanaan layanan tersebut. Sekolah menetapkan standar mutu proses pembelajaran yang disesuaikan dengan Standar Nasional Pendidikan. Sekolah senantiasa menyusun program yang diorientasikan pada perbaikan yang berkesinambungan dalam rangka meningkatkan kinerja sekolah. Hal tersebut dilakukan bersama dengan semua pihak sekolah. Dalam hal ini, sekolah juga melibatkan orang tua peserta didik dalam peningkatan mutu pendidikan. Sebagaimana yang diungkapkan oleh kepala sekolah bahwa sekolah menyusun program bersama-sama antara kepala sekolah, guru, orang tua peserta didik, dan komite sekolah. Ini sejalan dengan temuan sebelumnya bahwa pelibatan seluruh unsur sekolah, seperti orang tua sangat berpengaruh pada pemenuhan motivasi dan minat belajar peserta didik sehingga hal ini juga akan mempermudah guru dalam pengontrolan peserta didik di sekolah (Ardiyana et al., 
2019; Irma et al., 2019). Imbas yang lebih luas ialah sekolah mampu memiliki prestasi yang unggul karena ada peserta didik dengan pengetahuan maksimal yang tentu atas bantuan dari orang tua.

Penyusunan program sejatinya agar peserta didik terfasilitasi dengan baik sehingga motivasi belajar mereka meningkat. Sekolah berupaya untuk meningkatkan minat belajar dan daya serap peserta didik terhadap materi melalui kelengkapan sumber belajar, media, dan sarana prasarananya. Hal ini juga terlihat saat melakukan pengamatan dimana guru membawa media dan materi pembelajaran sebelum memulai pembelajaran. Dari pengamatan yang terlihat, guru terlihat terampil menggunakan media berbasis IT. Guru mengoperasikan laptop dengan terampil. Guru juga menampilkan powerpoint dan video yang telah dibuatnya. Guru juga nampak menambahkan materi yang ada pada buku dengan materi dari internet. Sebagaimana yang diungkapkan oleh kepala sekolah, "Kami melengkapi sumber belajar, media belajar, dan sarana prasarana untuk meningkatkan minat belajar peserta didik."

Temuan yang diperoleh sejalan dengan teori Lunenburg (2010) bahwa kunci pertanggungjawaban administrasi sekolah adalah manajemen sarana dan prasarana. Kebutuhan sarana dan prasarana tidak dapat dihindari. Ini juga terjadi oleh Permatasari (2014), bahwa sarana dan prasarana yang didapat di sekolah penelitian kurang memadai sehingga implementasi pendekatan saintifik dalam kurikulum 2013 di SMA Negeri 2 Batang kurang maksimal. Dari temuan tersebut, maka fungsi sarana dan prasarana sebagai alat kelancaran organisasi sangat dibutuhkan dan haruslah tersedia.

Selanjutnya, fungsi penggerakan atau implementasi merupakan tugas seluruh warga sekolah dalam suatu organisasi masing-masing. Sekolah berkomitmen untuk mewujudkan mutu pendidikan dengan maksimal. Beberapa upaya pun dilakukan sekolah agar dapat mencapai tujuan tersebut. Seperti yang dijelaskan oleh kepala SD Negeri Bulukantil bahwa sekolah meningkatkan mutu pendidikan di sekolah melalui penyediaan sarana dan prasarana yang mendukung. Temuan ini sejalan dengan hasil observasi di SD Negeri Bulukantil. Temuan observasi memperlihatkan adanya sarana dan prasarana untuk mendukung mutu pendidikan, seperti ruang computer, laptop untuk guru, ketersediaan dan kelengkapan buku di perpustakaan (buku fiksi dan non fiksi), ketersediaan wastafel dan kamar mandi yang bersih, serta sarana dan prasarana lain yang tersedia di sekolah. Sebagai cara menjaga keawetan sarana dan prasarana, kepala sekolah terlihat menugaskan penjaga sekolah untuk merawat setiap ruangan, seperti membersihkan dan mengganti ulang air kamar mandi, menyapu dan mengepel lantai, dan lain-lain.

Sarana dan prasarana merupakan dua hal yang tidak bisa dipisahkan. Keduanya berperan penting dalam terwujudnya tujuan pendidikan nasional. Selain melalui sarana dan prasarana, kepala sekolah juga memberikan layanan kepada pelanggan melalui pendidikan karakter, akademik, ekstrakurikuler, dan lain lain. Hal ini sesuai dengan yang dipaparkan kepala sekolah bahwa sekolah memberikan pelayanan kepada pelanggan melalui pendidikan karakter, pendidikan akademik, pendidikan ekstrakurikuler yang beragam juga kami sediakan, dan lain lain.

Berikutnya, penjelasan tentang pengukuran. Pelayanan yang diberikan diaplikasikan dalam kegiatan sehari-hari di sekolah. Sekolah selalu mengidentifikasi kebutuhan pelanggannya melalui rapat terbuka dengan orang tua peserta didik atau rapat tertutup di sekolah. Kegiatan supervisi juga dilakukan sekolah. Studi observasi memperlihatkan bahwa kepala sekolah rutin mengadakan rapat dengan guru di setiap minggunya. Tidak hanya itu, sesekali dalam sebulan, kepala sekolah juga melakukan pertemuan dengan orang tua siswa tepatnya di hari Sabtu akhir bulan. Hal ini juga diungkapkan oleh kepala sekolah, "Kami melakukan rapat dengan orang tua peserta didik atau juga internal. Beberapa kali melalui supervisi." 
Sekolah memiliki target setiap bulannya agar dilakukan pertemuan dengan pelanggan atau orang tua peserta didik. Hal lain yang bisa dilakukan yaitu dengan wawancara langsung untuk mengukur kepuasan mereka. Salah satu yang menjadi komitmen sekolah dalam perwujudan mutu pendidikan yakni adanya program-program unggulan sekolah. Sebagaimana yang diungkapkan Kepala Sekolah, "Kami memiliki program unggulan yang menjadi daya tarik masyarakat dengan kegiatan ekskul tari dan pramuka."

Kegiatan ekskul dilakukan setiap minggunya, seperti kegiatan pramuka. Peserta didik terlihat mengikuti esktrakurikuler wajib (pramuka) setiap hari Jum'at pukul 13.00 sampai dengan 15.30 WIB. Sementara itu, ekskul tari dilaksanakan setiap hari Rabu setelah pulang sekolah. Peserta didik nampak antusias mengikuti ekskul tari. Kegiatan tersebut didampingi oleh guru pendamping dan pelatih khusus tari.

Selain hal tersebut, sekolah telah menerapkan penilaian pembelajaran yang sesuai dengan aturan pemerintah. Penilaian/pengukuran digunakan untuk membantu memahami kebutuhan manusia sehingga dapat mengukur keberhasilan yang telah diperoleh (Nasution, 2015). Sekolah mengembangkan kualitas dan kuantitas sekolah melalui ketersediaan sarana prasarananya. Untuk menindaklanjuti hal tersebut, sekolah melakukan supervisi internal. Berbagai upaya untuk mengukur mutu pendidikan sekolah telah dilakukan, seperti wawancara dan angket. Hasil tersebut kemudian dirapatkan internal atau dengan supervisi.

Terakhir, mengenai pengawasan dilakukan dengan cara pengembangan dan evaluasi kerja. Pengembangan dan evaluasi kinerja guru juga dilakukan sekolah. Biasanya dilakukan melalui supervisi. Pendidikan dan pelatihan guru telah dilakukan sekolah untuk meningkatkan kualitas sumber daya manusia di sekolah. Perbaikan dan peningkatan sistem pendidikan berkelanjutan, baik pelayanan internal maupun ekternal terus dikembangkan melalui evaluasi (Rahmah, 2018). Beberapa kali sekolah melakukan pengukuran kinerja guru secara internal maupun dengan dinas terkait. Guru yang berprestasi akan diberikan penghargaan secara simbolik dan uang pembinaan. Bentuk penghargaan yang diberikan terpampang jelas di Ruang Guru dan Kepala Sekolah. Hasil observasi memperlihatkan banyaknya piala dan sertifikat penghargaan yang dipajang oleh guru di etalase.

Dengan demikian, pelaksanaan TQM di SD Negeri Bulukantil telah dipenuhi oleh stakeholder sekolah melalui tahap perencanaan, pengorganisasian, penggerakkan, pengukuran, dan pengawasan. Kepala sekolah berperan aktif untuk mengaktifkan guru, memperbaiki kualitas sekolah, dan menambah kuantitas sekolah. Pelayanan yang baik menjadi tujuan sekolah yang harus dinikmati pelanggan.

\section{SIMPULAN}

Penelitian ini menghasilkan dua kesimpulan. Pertama, kepala sekolah telah berperan dalam berbagai aspek pelaksanaan TQM, seperti aspek educator, manajer, administrator, leader, innovator, motivator, dan supervisor dengan presentase yang diperoleh secara keseluruhan 81,24\%. Kedua, pelaksanaan TQM di SD Negeri Bulukantil telah berjalan sesuai dengan tahap perencanaan, pengorganisasian, penggerakan, pengukuran, dan pengawasan. Temuan penelitian ini dapat menjadi rujukan bagi para peneliti mendatang mengenai indicator peran kepala sekolah dan tahapan pelaksanaan TQM di sekolah. Peneliti mendatang juga dapat menguji pelaksanaan TQM terhadap kepuasaan orang tua peserta didik.

\section{DAFTAR PUSTAKA}

Anjarwati, L. (2016). Peran kepala sekolah dalam mengimplementasikan TQM untuk 
meningkatkan mutu pendidikan agama islam. Perspektive, 09(1), 37-50.

Ardiyana, R. D., Akbar, Z., \& Karnadi, K. (2019). Pengaruh keterlibatan orang tua dan motivasi intrinsik dengan kepercayaan diri anak usia dini. Jurnal Obsesi : Jurnal Pendidikan Anak Usia Dini, 3(2), 494. https://doi.org/10.31004/obsesi.v3i2.253

Creswell, J. W. (2014). Research design: Qualitative, quantitative and mixed methods. In Approaches: Fourth edition. Sage Publication.

Danim, S. (2006). Visi baru manajemen sekolah. Bumi Aksara.

Esia-donkoh, K. (2018). Instructional supervisory practices of headteachers and teacher motivation in public basic schools in anomabo education circuit. 5(1), 43-50. https://doi.org/10.20448/journal.509.2018.51.43.50

Fitrah, M. (2017). Peran kepala sekolah dalam meningkatkan mutu pendidikan. Jurnal Penjamin Mutu Pendidikan, 3(1), 31-42.

Haryanto, \& Lurah. (2014). Peran kepemimpinan kepala sekolah dalam penerapan Manajemen Berbasis Sekolah (MBS) di SDIT Jabal Nur Gamping, Sleman. Jurnal Akuntabilitas Manajemen Pendidikan, 2(2), 174-187.

Hidayati. (2015). Kepemimpinan dan peningkatan mutu pendidikan. Jurnal Tarbiyah, 22(1), 48-65.

lqbal, S., Guohao, L., \& Akhtar, S. (2017). Effects of job organizational culture, benefits, salary on job satisfaction ultimately affecting employee retention. Review of Public Administration and Management, 05(03). https://doi.org/10.4172/2315-7844.1000229

Irma, C. N., Nisa, K., Sururiyah, S. K., Fkip, P., Peradaban, U., Asahan, P. F. U., \& Stainu, P. P. A. I. (2019). Keterlibatan orang tua dalam pendidikan anak usia dini di TK Masyithoh 1 Purworejo. Jurnal Obsesi : Jurnal Pendidikan Anak Usia Dini, 3(1), 214-224. https://doi.org/10.31004/obsesi.v3i1.152

Jusuf, R. S. (2013). Analisis pengaruh TQM, Sistem pengukuran kinerja dan reward terhadap kinerja manajerial. Jurnal Riset Ekonomi, Manajemen, Bisnis Dan Akuntansi, 1(3), 634-644. https://doi.org/10.35794/emba.v1i3.1870

Kementerian Pendidikan dan Kebudayaan. (2015). Penilaian kinerja kepala sekolah. Kementerian Pendidikan dan Kebudayaan.

Lubis, U. (2015). Pelaksanaan manajemen berbasis sekolah dalam meningkatkan mutu lulusan di SMA Islam Al-Ulum Terpadu Medan. Analytica Islamica, 4(1), 167-186.

Lunenburg, F. (2010). School facilities management. National Forum of Educational Administration \& Supervision Journal, 27(4), 1-7.

Marmoah, S. (2016). Pengelolaan pendidikan dalam upaya pemberdayaan guru sekolah dasar berbasis soft skill di Kota Jambi. Jurnal IImiah Dikdaya, 6(2), 6872.

Mulyasa, E. (2011). Manajemen berbasis sekolah konsep, strategi dan pelaksanaan. Remaja Rosdakarya.

Nasution. (2015). Manajemen mutu terpadu. Ghalia Indonesia.

Nurhayati, Amin, B. D., \& Nurhilaliyah. (2018). Pelatihan penyusunan Lembar Kegiatan Peserta Didik (LKPD) berbasis inquiry. Prosiding Seminar Nasional LPPM Universitas Negeri Makasar, 553-555.

Permatasari, E. A. (2014). Implementasi pendekatan saintifik dalam kurikulum 2013 pada pembelajaran sejarah. Indonesian Journal of History Education, 3(1), 1116.

Prestiadi, D., Hardyanto, W., \& Pramono, S. E. (2015). Implementasi Total Quality Management (TQM) dalam mencapai kepuasan siswa. Educational Management, 4(2), 107-115.

Purwanti, S. (2013). Peran kepemimpinan kepala sekolah dalam meningkatkan disiplin kerja guru dan pegawai di SMA Bakti Sejahtera Kecamatan Kongbeng 
Kabupaten Kutai Timur. E-Journal Administrasi Negara, 1(1), 210-224.

Rahmah, U. (2018). Pelaksanaan Total Quality Management (TQM) di SD Al-Hikmah Surabaya. Manageria: Jurnal Manajemen Pendidikan Islam, 3(1), 111-131.

Sahertian. (2000). Konsep dasar dan teknik supervisi pendidikan. Rineka Cipta.

Sugiyono. (2016). Metode penelitian kualitatif, kuantitatif, dan R\&D. Alfabeta.

Supriyanto, A. (2011). Total quality management. Cakrawala Pendidikan, 40(1), 54-59. https://doi.org/10.1177/001088049904000123

Wahjosumidjo. (2005). Kepemimpinan kepala sekolah, tinjauan teori dan. permasalahannya. Raja Grafindo Persada.

Yang, F., Liu, J., Huang, X., Qian, J., Wang, T., Wang, Z., \& Yu, H. (2018). How supervisory support for career development relates to subordinate work engagement and career outcomes: The moderating role of task proficiency. Human Resource Management Journal, 28(3), 496-509. https://doi.org/10.1111/1748-8583.12194

Zahroh, A. (2015). Total quality management: capaian kualitas output melalui sistem kontrol mutu sekolah. Cendekia, 9(1), 79-94. 